Das: China: Epitome of an Emerging Market

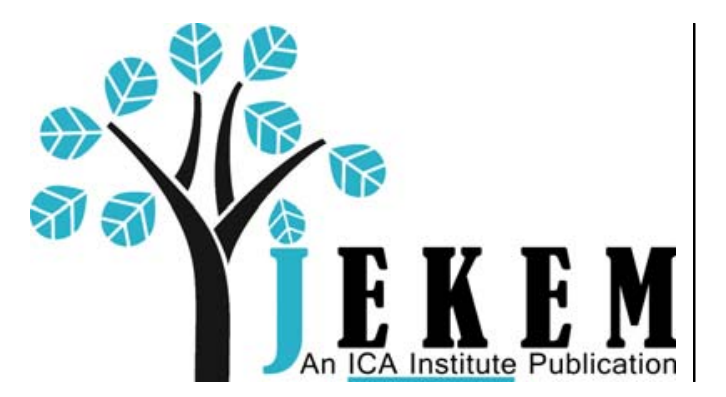
India, China and America Institute
1549 Clairmont Road, Suite 202 - Decatur, Ga 30033 USA

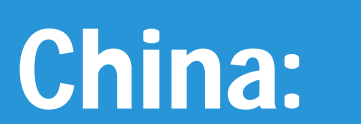

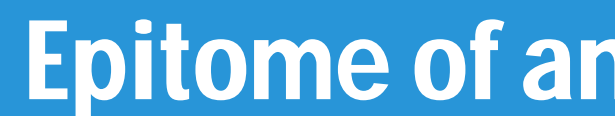

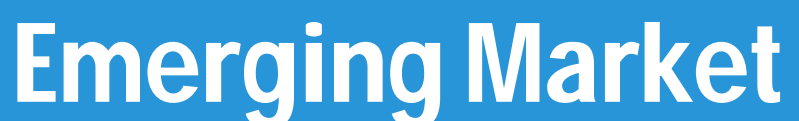

Dilip K. Pas

Journal of Emerging Knowledge on Emerging Markets

November 2011

Published by DigitalCommons@Kennesaw State University, 201 


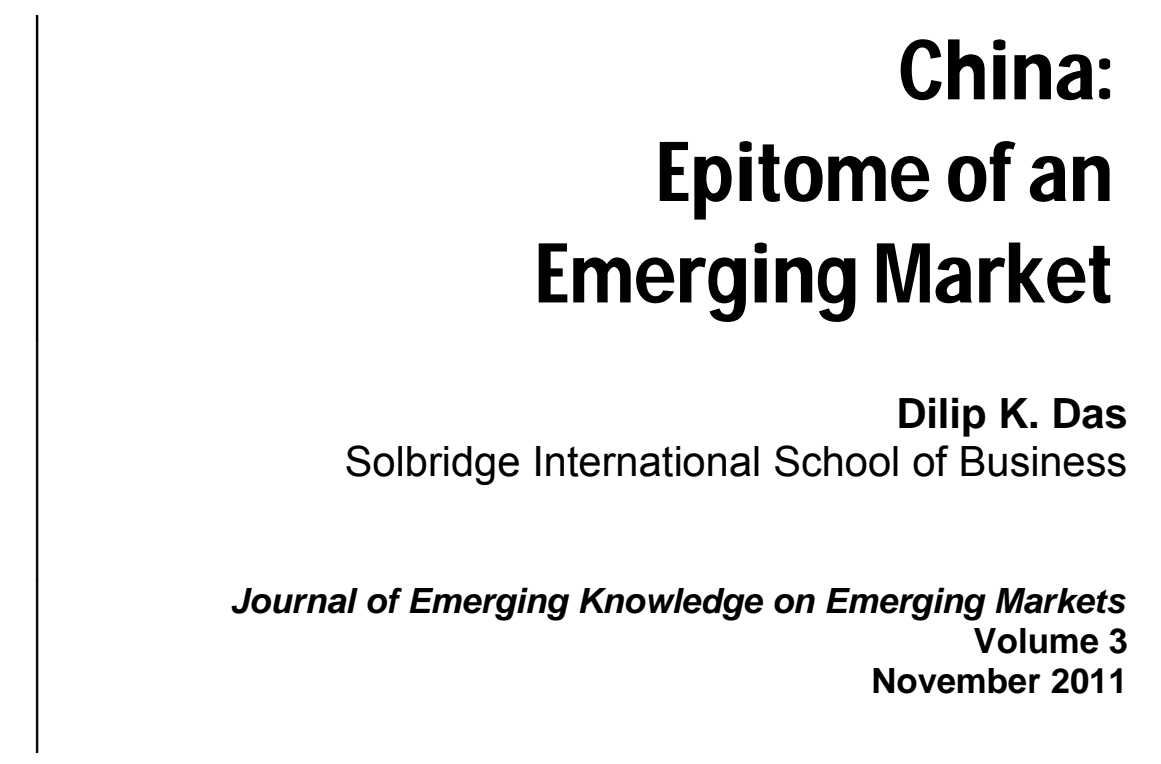

I think that when somebody writes the history of our time 50 or 100 years from now, it is unlikely to be about the great recession of 2008. It is also unlikely to be about the fiscal problems that America confronted in the second decade of the 21st century. It will be about how the world adjusted to the movement of the theatre of history towards China. Lawrence H. Summers (2010)

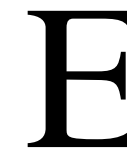
conomists, public policy mandarins and decision-makers in the business community the world over have been awestruck by the People's Republic of China's (hereafter China) vertiginous GDP growth, relentless economic ascent, sustained capital accumulation, large changes in sectoral composition of output, escalating regional and global heft and integration with the regional and global economies. With the prompt and timely support of countercyclical macroeconomic policy measures, China weathered the global financial maelstrom of 2007-9 resiliently, which indisputably accentuated its importance in the regional and global economies. Although China's GDP growth decelerated during the crisis period, the economy never suffered a recession. Chinese demand helped to pull a number of economies into recovery. It led the global recovery and contributed to the recovery efforts of the Asian emerging-market economies (EMEs). Without China's support the so-called Great Recession would have been more severe, deeper and lasted longer (Das, 2011a). 
If an EME is defined as an economy that is advancing towards becoming an advanced industrial economy, as testified by its rapid GDP growth and pace of industrialization, China is an epitome of EME. An EME tends to have lower per capita income and business and industrial activities than an advanced industrial economy but much higher GDP growth rate. The heft of an EME in the global economy is usually on the ascendance. The Chinese economy has been demonstrating all these idiosyncratic characteristics of an EME for some time. As the largest EME, the largest creditor country, the fastest growing economy and the oldest continuous civilization and still run by a one-party communist bureaucracy, China occupies a unique position. After almost two centuries of conflict and humiliation by foreign powers, China is on its way to returning to the center of the global economy, a position it held between 1300 and 1820 (Maddison, 2006).

During what became known as the Great Recession and recovery China, in collaboration with some of the other Asian EMEs, continued to drive global growth and global productivity growth (Das, 2011a). During the global recession of 2009, the Chinese economy displayed an astounding ability to grow at 9.2 percent. In 2009, China's share of global growth was almost the same (90 percent) as all the advanced industrial economies put together. In 2010, the year of global recovery, China accounted for about a third of global growth (Makin, 2011). After growing at the rate of 10.3 percent in 2010, the Chinese economy was showing no signs of slowing down or descending to a lower growth trajectory in 2011. The International Monetary Fund (2011) has projected its 2011 GDP growth rate at 9.6 percent and 2012 growth rate at 9.5 percent. ${ }^{1}$ At this juncture, China's economic boom has entered into its fourth decade. While the crisis and recession (2007-9) left deleterious effects over other economies, particularly over the advanced industrial economies, they managed to enhance China's relative regional and global economic and financial prominence. The post-crisis Chinese economy is widely regarded as the principal engine of regional and global growth.

The objective of this article is first to provide an exposition of the fact that instituting market-oriented macroeconomic reforms, liberalizing the economy and institutional upgrading turned China, a centrally planned command economy, productively and profitably towards a market mechanism and a free-enterprise economy. These strategic measures created turned China into an EME in a record time span of a generation. This article highlights China's stupendous economic achievements in areas of growth and industrialization. The end result of these measures drew approbation of academics, policy mandarins and business leaders in the rest of the world. Initially this transformation was slow but it has accelerated since the early 1990s, albeit state control of the economy and intervention in it were not abandoned.

Reforms and restructuring measures had a deterministic effect on China's rate and pattern of growth. In thirty-two years, China rose from a marginal and systemically insignificant

${ }^{1}$ The source of statistical data used here is IMF (2011). 
economy to the second largest in the world; this was a veritable economic miracle. In a succinct manner, this article traces the myriad stages, events and structural transformations along China's growth path. While adopting the free-market doctrine, the government emphasized prudent fiscal policy, privatization, maintaining a balanced budget and aimed for low inflation. Switching from a centrally planned, command economy framework to a market mechanism was not only a momentous policy change but also "was the single most important cause of the on-going expansion in productivity” (Bernanke, 2006). Turning to the free-market system also explains China's export success "much more than the principle of comparative advantage” (Rodrik, 2006).

\section{Economic Growth and Transition}

In the early 1980s, China was an agrarian, impoverished, inward-looking, low-income and a near autarkic economy. At the time of launching its market-oriented macroeconomic reforms in 1978 its per capita income was $\$ 182$ and trade-to-GDP ratio 9.7 percent. At this juncture, China's exports amounted to $\$ 9.8$ billion, or 0.6 percent of the multilateral exports. China’s total trade in 1978 was $\$ 21$ billion. Quantitative planning of trade was done by a handful of foreign trade corporations and it had no relation to China's comparative advantage. These statistics attest that China was an absolutely marginal economy and that it began its rise to global prominence from a very low base. Summers (2007) pointed out that in a span of three decades China has experienced the same degree of industrialization that took two centuries to occur in Europe.

\section{Superlative Growth Performance}

Few parallels are available to China's rapid GDP growth performance in economic history. China established itself as an economy with the highest long-term average GDP growth rate in real terms in the fastest growing region of the global economy. It achieved this distinction without suffering from any major crisis or sharp interruption in the growth process, which were common in the other EMEs. Beyond any shadow of doubt it is an exceedingly dynamic economy, which has successfully integrated both regionally and globally.

A prominent recent development in the arena of international economy was China storming up the league tables to overtake Japan in the second quarter of 2010. It reached the second slot in the table of the world's largest economies. Japan was the second largest global economy for over four decades. This was a symbolic moment for China, because in terms of dynamism and economic influence China had outpaced Japan a long time ago. The annual 2010 GDP figures were as follows: Japan’s GDP was \$5.5 trillion while China's $\$ 5.9$ trillion. It was well neigh impossible to visualize in 1978 that China would achieve this enviable distinction in a short time span of three decades. This was the time when the CPC 
adopted its renowned Deng doctrine, the Gai Ge Kai Fang, or "change the system, open the door” strategy, which in turn incited the Chinese economy's celebrated U-turn.

Various time points have been computed for China to become the largest global economy. According to The Economist (2010b) China will eclipse the US and be the number one economy in 2019. According to an Australian government white paper, "by some measures, China has the potential to overtake the US as the world's largest economy around 2020". In an upgraded forecast, Goldman Sachs' chief economist Jim O'Neill reported that China will overtake the US economy by 2027 (The Economist, 2010a). However, the renowned economic historian Angus Maddison projected 2030 as the time point for China reaching the top (Maddison, 2001). Public perception regarding who is leading at present is interesting. According to the Gallup's World Affairs survey of February 2011, 52 percent of the Americans responded that China is the leading global economy, while 32 percent perceived the US as the largest (Gallup, 2011).

During the periods of global slowdown China was an important source of growth. It holds true for $2001-03^{3}$ and 2009 and also during the recovery of 2010 (section 1). China succeeded in sustaining a near 10 percent real GDP growth rate for three decades. Rapid growth also sharply reduced the proportion of the population living in absolutely poverty. A recent World Bank (2009) report testified that between 1981 and 2004, the fraction of China's population consuming $\$ 1$ a day in today's purchasing power fell from 65 percent to 10 percent; as a consequence half a billion people were lifted out of poverty. This magnitude of decline in poverty in such a short time span has no historical precedent. In rural China, the poverty rate plummeted from 18.5 percent in 1981 to 2.8 percent in 2004 (Chaudhury and Ravallion, 2007). It has either achieved most of the Millennium Development Goals (MDGs) or is close to doing so. Compared to the late 1970s, improvement in the quality of life and economic development has been nothing short of phenomenal.

\section{Structural Transformation}

During the three-decade-long comprehensive reform period China's economy underwent a profound transformation. Traditionally the structure of an economy is divided into primary (agriculture and extractive activities), secondary (industry and manufacturing) and tertiary (services) sectors. The earlier theorists on economic growth regarded structural transformation an essential condition for attaining high rate of per capita income growth or growth of output per worker (Lewis, 1954; Kuznets, 1979). Structural transformation essentially implies that the factors of production are reallocated from less productive sectors or industries to more productive ones. It was regarded as a source of growth by the eminent

\footnotetext{
${ }^{2}$ Quoted in The Australian, May 2, 2009.

${ }^{3}$ Prasad and Rumbaugh (2004) show that during 2001-03 China accounted for 24 percent of global growth measured in purchasing power parity terms.
} 
scholars of the post-World War Two period. The concept of structural change and factor reallocation was the basis of Chenery et al.'s (1986) theory of economic development. They regarded factor reallocation as vitally important in explaining economic growth and performance. Lucas (1993) and Verspagen (1993) also constructed models of industrial development in developing economies. The former took supply-side variables, while the latter took demand-side variables. Both laid a great deal of emphasis on the importance of structural change in growth as well as in total factor productivity (TFP) growth. From this perspective the Chinese economy is a fortuitous research case. Sectoral reallocation of resources as well as their reallocation across manufacturing firms has been a key source of productivity growth for the Chinese economy. The rate of return on investment has remained well above 20 percent (Song et al., 2011).

As stated in section 2.3 below, China's total GDP and industrial output increased several times over the three-decade-long comprehensive reform period. The manufacturing sector expanded even at a faster pace than the GDP. The manufacturing sector recorded robust growth and maintained its dominance of the Chinese economy throughout the reform period (Table 1 and Graph 1). In 2008, it was the largest sector, accounting for 48.1 percent of GDP. Except for the early 1990s, manufacturing accounted for around 50 percent of the GDP. The only exception to this was the 1994-2000 period, when the industrial sector produced more than 50 percent of the total GDP. 
China: Epitome of an Emerging Market

\section{Table 1}

Gross Domestic Product at Constant Prices

\begin{tabular}{|c|c|c|c|c|c|c|}
\hline Year & $\begin{array}{c}\text { Gross } \\
\text { Domestic } \\
\text { Product } \\
\text { (100 million } \\
\text { yuan }) \\
\end{array}$ & $\begin{array}{l}\text { Primary / } \\
\text { Agriculture } \\
\text { (\%) }\end{array}$ & $\begin{array}{l}\text { Secondary / } \\
\text { Industry } \\
\text { (\%) }\end{array}$ & $\begin{array}{c}\text { Manu- } \\
\text { facturing } \\
(\%)\end{array}$ & $\begin{array}{l}\text { Cons- } \\
\text { truction } \\
(\%)\end{array}$ & $\begin{array}{c}\text { Tertiary / } \\
\text { Services } \\
\text { (\%) }\end{array}$ \\
\hline & & & Price Base Year $=1$ & & & \\
\hline 1978 & 3548.2 & 26.4 & 49.8 & 93.1 & 6.9 & 23.8 \\
\hline 1979 & 3816.9 & 26.0 & 50.1 & 93.5 & 6.5 & 23.9 \\
\hline \multirow[t]{2}{*}{1980} & 4116.2 & 23.8 & 52.7 & 92.8 & 7.2 & 23.5 \\
\hline & & & Price Base Year $=19$ & & & \\
\hline 1980 & 4567.9 & 30.0 & 48.5 & 91.2 & 8.8 & 21.5 \\
\hline 1981 & 4807.4 & 30.5 & 46.9 & 91.1 & 8.9 & 22.6 \\
\hline 1982 & 5242.8 & 31.2 & 45.4 & 91.2 & 8.8 & 23.4 \\
\hline 1983 & 5811.8 & 30.5 & 45.2 & 90.7 & 9.3 & 24.3 \\
\hline 1984 & 6693.8 & 29.9 & 44.9 & 91.0 & 9.0 & 25.2 \\
\hline 1985 & 7595.2 & 26.8 & 46.9 & 90.7 & 9.3 & 26.2 \\
\hline 1986 & 8267.1 & 25.5 & 47.5 & 90.2 & 9.8 & 27.0 \\
\hline 1987 & 9224.7 & 23.9 & 48.4 & 89.9 & 10.1 & 27.7 \\
\hline 1988 & 10265.3 & 22.0 & 49.8 & 90.5 & 9.5 & 28.1 \\
\hline 1989 & 10682.4 & 21.8 & 49.7 & 91.6 & 8.4 & 28.5 \\
\hline \multirow[t]{2}{*}{1990} & 11092.5 & 22.5 & 49.4 & 91.7 & 8.3 & 28.1 \\
\hline & & & Price Base Year $=1$ & & & \\
\hline 1990 & 18547.9 & 27.3 & 41.6 & 88.9 & 11.1 & 31.1 \\
\hline 1991 & 20250.4 & 25.6 & 43.4 & 89.3 & 10.7 & 31.0 \\
\hline 1992 & 23134.2 & 23.5 & 46.0 & 89.3 & 10.7 & 30.5 \\
\hline 1993 & 26364.7 & 21.6 & 48.4 & 89.5 & 10.5 & 30.0 \\
\hline 1994 & 29813.4 & 19.8 & 50.7 & 89.9 & 10.1 & 29.5 \\
\hline 1995 & 33070.5 & 18.8 & 52.0 & 90.0 & 10.0 & 29.2 \\
\hline 1996 & 36380.4 & 17.9 & 53.0 & 90.3 & 9.7 & 29.1 \\
\hline 1997 & 39762.7 & 17.0 & 53.6 & 91.0 & 9.0 & 29.5 \\
\hline 1998 & 42877.4 & 16.3 & 54.1 & 91.0 & 9.0 & 29.6 \\
\hline 1999 & 46144.6 & 15.6 & 54.4 & 91.3 & 8.7 & 30.1 \\
\hline 2000 & 50035.2 & 14.7 & 54.9 & 91.6 & 8.4 & 30.4 \\
\hline
\end{tabular}


Table 1 (cont'd)

\section{Gross Domestic Product at Constant Prices}

\begin{tabular}{|c|c|c|c|c|c|c|}
\hline \multirow[b]{2}{*}{2000} & \multicolumn{6}{|c|}{ Price Base Year=2000 } \\
\hline & 99214.6 & 15.1 & 45.9 & 87.9 & 12.1 & 39.0 \\
\hline 2001 & 107449.7 & 14.3 & 46.0 & 88.1 & 11.9 & 39.7 \\
\hline 2002 & 117208.3 & 13.5 & 46.3 & 88.2 & 11.8 & 40.2 \\
\hline 2003 & 128958.9 & 12.6 & 47.4 & 88.2 & 11.8 & 40.0 \\
\hline 2004 & 141964.5 & 12.1 & 47.8 & 88.6 & 11.4 & 40.0 \\
\hline \multirow[t]{2}{*}{2005} & 158020.7 & 11.5 & 48.2 & 88.2 & 11.8 & 40.4 \\
\hline & \multicolumn{6}{|c|}{ Price Base Year=2005 } \\
\hline 2005 & 184937.4 & 12.1 & 47.4 & 88.2 & 11.8 & 40.5 \\
\hline 2006 & 208381.0 & 11.3 & 47.7 & 87.8 & 12.2 & 41.0 \\
\hline 2007 & 237892.8 & 10.3 & 48.0 & 87.6 & 12.4 & 41.7 \\
\hline 2008 & 260812.9 & 9.9 & 48.1 & 87.7 & 12.3 & 42.0 \\
\hline
\end{tabular}

a) There are two figures at the base switching year, one at the former base year prices, another at the latter.

b) Please refer to the brief introduction for the defination of gross domestic product at constant prices.

Source: China Statistical Yearbook 2010. Beijing. China. China Statistics Press. 


\section{Graph 1}

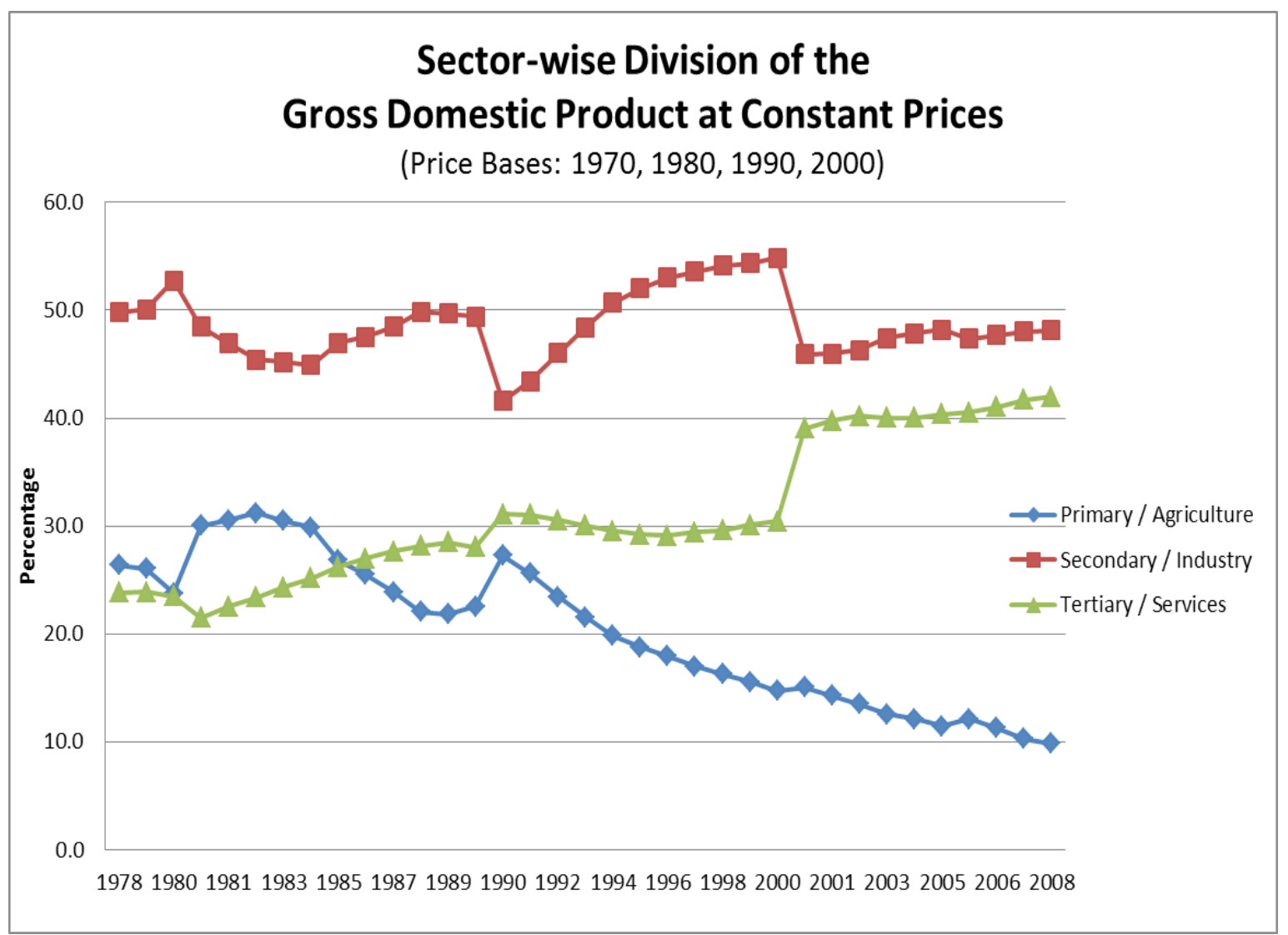

Source: China Statistical Yearbook 2010. Beijing. China. China Statistics Press.

Chen et al. (2011) estimated the stochastic frontier sectoral production function and concluded that TFP growth exceeded the quantitative growth of inputs since 1992. Using a decomposition technique, they also found that the structural transformation in the Chinese economy substantially contributed to TFP and output growth but decreasingly over time. This empirical analysis inferred that the market reforms and changes in industrial structure significantly accounted for the overall trend and the sectoral heterogeneity of factor allocative efficiency during the process of rapid industrial growth. The industrial sector in the Chinese economy will continue to remain dominant in the foreseeable future because of extensive investment that has been made in the manufacturing capacities. Besides, while the level of education in the Chinese society has improved in the recent past, it has not progressed so much as to carve out and support a robust and dynamic services sector of the kind that the advanced industrial economies have developed. This group of economies is known for its knowledge-intensive business services. 
One prominent sectoral transformation occurred in the shifting roles of the primary and tertiary sectors. The primary sector was close to a quarter of the GDP in the late 1970s. It rose first in importance to approximately one-third in 1984, but after 1991 went into a steady decline. In 2008, it contributed a paltry 9.9 percent of the total GDP. In contrast, the tertiary sector demonstrated a gradually bolstering trend. In the late 1970s, it accounted for only a quarter of the GDP, but in 1990 its contribution climbed to 31.1 percent. Its contribution to the GDP remained stationary for some time and in 2000 it was 30.4 percent. Tertiary sector activities expanded sharply after this juncture and in 2008 it accounted for 42 percent of the GDP (Table 1 and Graph 1). These transformations in the structure of the Chinese economy present a vivid picture of the dynamic growth in an economy that started from a low base and grew to be the second largest in the world. China's transformation to a tertiary sector dominated economy cannot occur in the short-term. However, given the swift stride of development the tertiary sector, it could unavoidably become a dominant sector in about a decade.

The present stage of China's industrialization is far from maturity. It is still in its initial stages. With the passage of time the economy will absorb more labor from the agricultural sector. It may go into labor-intensive industrial and other sectors. Parallel to the structural transformation indicated in the preceding paragraphs, the proportion of industrial valueadded went on increasing from an exceedingly low level of 17.6 percent in 1952 to a high level of 44.1 percent in 1978. In the pre-1978 period, China's industrial development was heavy-industry based. During the post-1978 reform era it changed to a mix of light and heavy industry. China's industrial value-added during this period stabilized around 40 percent (Chen et al., 2011). This level has been sustained until the present.

Other major areas of structural transformation were the burgeoning of a de novo private sector and dismantling of the SOE sector which was a distinguishing trait of the non-market economy period (section 2.7) and turning a nearly autarkic economy into an outwardoriented economy. In a short time span, China opened up to trade and investment flows in large measures. During the first decade of the twenty-first century China's trade-to-GDP ratio was 70 percent or above, much higher than that of other comparable EMEs. Since it acceded to the WTO in 2001, trade and FDI made larger contributions to China's GDP growth than before (Lawrence, 2008). Given its outward orientation, its rapid expansion and the fact that it is the second largest economy in the world, China is likely to have a large impact on the global trading system and pattern as well as its policies. It will be a force to reckon with in the future evolution of the global trading system. So far China has promoted multilateral trade liberalization as well as at regional level through free-trade agreements (FTAs).

\section{Dramatic Change in Global Economic Stature}

Long-term GDP growth statistics are available for 119 economies. Of these, the Korea and Taiwan recorded comparable long-term average GDP growth rates in the post-1960 period, 
although not equal to that of China. Diamond-rich Botswana also fared well. During the three decades of reform (1978-2008), “China’s total gross domestic product (GDP), industrial output, foreign trade and importantly, its per capita income increased respectively by factors of 16, 27, 124, and 12" (Golley and Song, 2010: 1). With the passage of time, China inaugurated an unambiguous shift in the contours of regional and global economic power balance. Its heft in the global economy increased at a swift pace. In terms of purchasing power parity (PPP), China's share of global GDP increased from 2.0 percent in 1980 to 12.52 percent in 2009. Computed in nominal dollars and market prices, this increase was from 2.6 percent to 8.3 percent over the same period (Dahlman, 2010).

Japan (in the 1960s) and the four Asian NIEs (in the 1970s) were also high performers during similar stages of their development and they won accolade from the global academic and policy-making establishment for their export-and-FDI-led rapid industrialization. However, due to the sheer size of China's GDP, its global economic impact is, and will be, much higher than that of any of the NIEs. In terms of systemic significance, it is far more important. The Japanese economy had a great deal of systemic significance and global impact during its high-growth period, but it entered a "deep slump" in the fourth quarter of 1991 (Bernanke, 2000, p. 149). Its real GDP growth rate in 1991Q4 through 1999Q4 was less than 0.9 percent per year. It is yet to recover from its self-induced paralysis. Japan's share in global GDP has been on a decline since 1991.

At the time of launching the reforms in the late 1970s, China's contribution to the growth of the world economy was less than 0.1 percent. In 2010, China became the main driver of global growth. It contributed 33 percent to the global growth (OECD, 2010). This reflected both the catch-up momentum in China and slower trend growth in the advanced industrial economies. It has also begun to have wide-ranging ramifications over global economic and financial architecture as well as in the areas of international business and investment. In November 2008, in the context of the severe global financial crisis, the first Group-ofTwenty (G-20) summit took place in Washington, DC. China and the US, as the two most important members of the G-20, were expected to propose initiatives to support the global economy and stabilize financial markets. For the record, it must be mentioned that according to the World Development Indicators 2010, China's GDP in current dollars was $\$ 4.98$ trillion in 2009. Its GNI per capita, also in current dollars, was $\$ 3,650$, making it a middle-income country. In terms of PPP its per capital income in 2009 was $\$ 6,890$ (World Bank, 2010). As shown in Table 2 and Graph 2, growth rates of these two vital indicators picked up in the twenty-first century. 


\section{Table 2}

\section{GNI Per Capita Income in PPP and Market Exchange Rate (in dollars)}

\begin{tabular}{|c|c|c|}
\hline Year & PPP (in \$) & Market Exchange Rate (in \$) \\
\hline 1980 & 250 & 220 \\
\hline 1981 & 280 & 220 \\
\hline 1982 & 320 & 220 \\
\hline 1983 & 370 & 220 \\
\hline 1984 & 440 & 250 \\
\hline 1985 & 500 & 280 \\
\hline 1986 & 550 & 310 \\
\hline 1987 & 620 & 320 \\
\hline 1988 & 700 & 330 \\
\hline 1989 & 750 & 320 \\
\hline 1990 & 800 & 330 \\
\hline 1991 & 890 & 350 \\
\hline 1992 & 1,020 & 390 \\
\hline 1993 & 1,180 & 410 \\
\hline 1994 & 1,340 & 460 \\
\hline 1995 & 1,480 & 530 \\
\hline 1996 & 1,650 & 650 \\
\hline 1997 & 1,820 & 750 \\
\hline 1998 & 1,960 & 790 \\
\hline 1999 & 2,120 & 840 \\
\hline 2000 & 2,340 & 930 \\
\hline 2001 & 2,560 & 1000 \\
\hline 2002 & 2,830 & 1100 \\
\hline 2003 & 3,180 & 1270 \\
\hline 2004 & 3,590 & 1500 \\
\hline 2005 & 4,130 & 1,760 \\
\hline 2006 & 4,790 & 2,050 \\
\hline 2007 & 5,640 & 2,490 \\
\hline 2008 & 6,280 & 3,050 \\
\hline 2009 & 6,890 & 3,650 \\
\hline
\end{tabular}

Source: The World Bank (2010). World Development Indicator Online Database. Washington DC. 


\section{Graph 2}

\section{GNI Per Capita Income in PPP and Market Exchange Rate \\ (in dollars)}

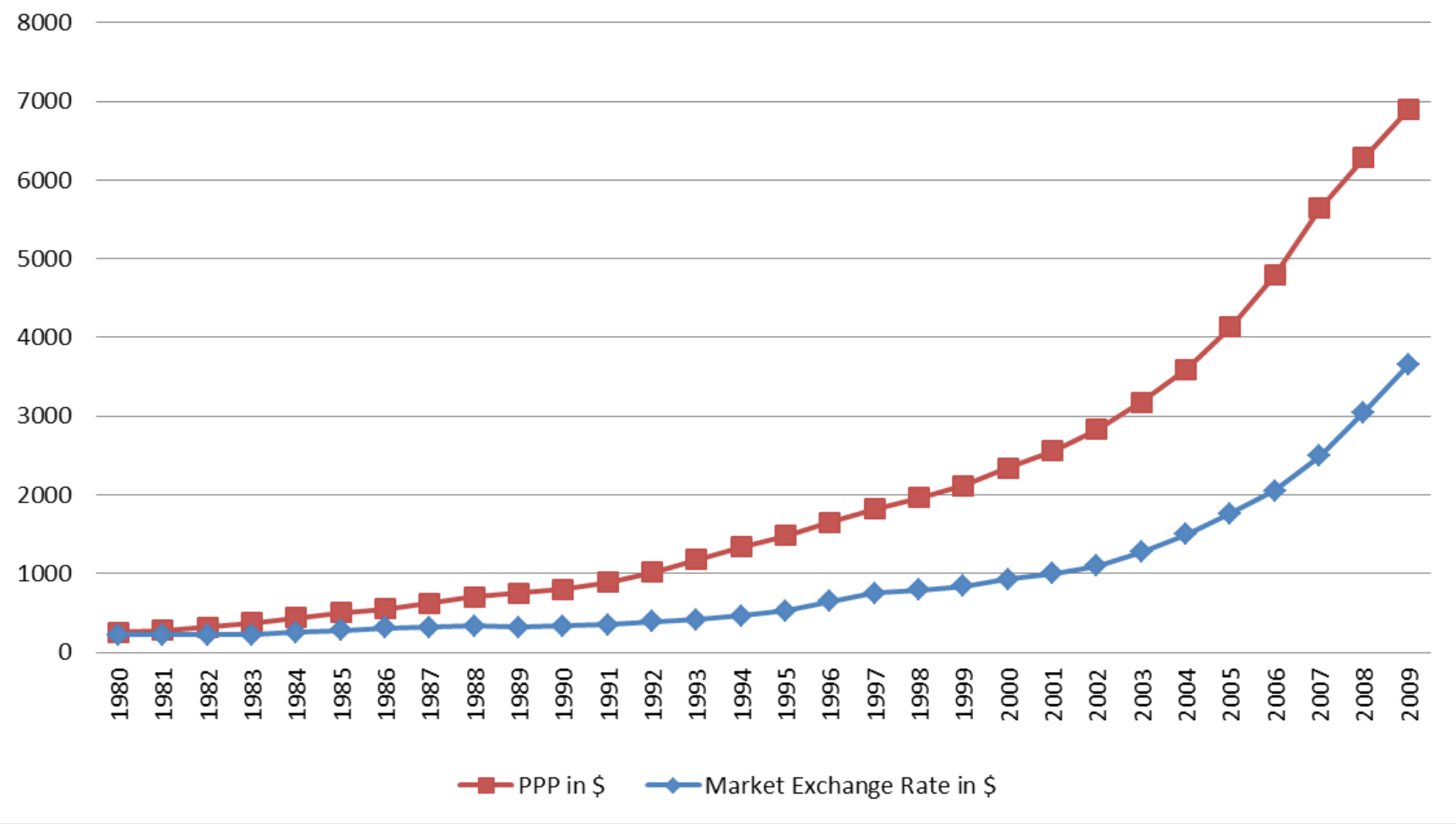

Source: The World Bank (2010). World Development Indicator Online Database. Washington DC.

From a completely peripheral economy approximately three decades ago, China became the third largest in the world in 2007, measured in market prices and exchange rates, and the second largest in 2010. By 2009, it had become the largest exporter, when the value of its exports was \$1,202 billion (or 9.6 percent of the total multilateral exports). China edged out Germany and the US to be world's biggest trading power. In 2009 those countries followed China with 9.0 percent and 8.5 percent shares in total, respectively (WTO, 2010). Since 2005, measured by cargo tonnage Shanghai has been the world's busiest port. In 2009, China also became the largest energy consumer. It is also the largest consumer and importer of iron ore, aluminum, copper, nickel, potash and timber products (Das, 2011b). According to Standard and Poor's 2010 ranking, five of the 50 largest banks in the world are Chinese. Rising prosperity has ushered in dramatic lifestyle changes in China. 


\section{Growing Middle and Affluent Classes}

Three decades of rapid clip growth has propelled China into the ranks of lower-middleincome countries with a swiftly emerging middle-class (WB, 2011). ${ }^{4}$ Not only has the size of China's middle class grown significantly, but the McKinsey Global Institute has also highlighted the rise of an urban middle class whose spending power will soon redefine the Chinese market. These urban affluent consumers earn more than Rmb 100,000 (or \$12,500) a year and command Rmb 500 billion, which is approximately 10 percent of urban disposable income (Farrell et al., 2006). This segment of consumers has cultivated a taste for globally branded luxury goods. They regard them as the de rigueur symbol of social status. This class of well-off customers is swelling by the year. According to the March 2011, Forbes list of billionaires, China has 115 on the mainland alone.

Income elasticity of demand for luxury goods is usually regarded as very high, much higher than 1. Therefore, confident Chinese consumers have become a key factor for the global luxury goods market. China's big cities now have gleaming new high-end shopping malls and glitzy boutique. The global financial crisis did not adversely affect the super-rich segment of the Chinese market. The luxury goods market in China bucked the trend during 2009; while global sales fell by 8 percent across the globe China recorded an estimated growth of 12 percent (KPMG, 2010).

The global size of the luxury brand goods market is $\$ 80$ billion; Chinese consumers shopping at home and abroad accounted for 10 percent of total global sales. According to a KMPG (2010) study, China was the second largest luxury market in the world after Japan in 2010. However, by 2014, China is projected to be the largest market for luxury goods (Chadha and Husband, 2007). It is also the second-largest market for Rolls Royce cars, the perennial financial status symbol, accounting for 20 percent of total sales in 2010 (Daily Telegraph, 2011). Largely due to Chinese customers, 2010 recorded a 57 percent sales increase in luxury brands of Swiss watches, like Cartier, Piaget and Vacheron Constantin. China is the fastest growing market for the high-priced, classic, ultra-thin dress watches manufactured in Switzerland. In 2009, China accounted for 5.3 percent of total Swiss exports, compared with 0.2 percent in 2000, and 2.7 percent in 2005. Omega has 180 stores in China, including 15 directly-owned ones. Some of the Omega watches, like the Constellation line, are enormously popular with the prosperous Chinese. Although Omega is a global company and does not design its products according to markets, in 2009, Omega redesigned an entire line to appeal to Chinese taste and launched it in Shanghai (Koresnikov-Jessop, 2010).

For China's nouveau riche Chateau Lafite has become a drink of choice, which has been driving its prices into the stratosphere (Stimpfig, 2011). Some of the toniest luxury brands are scrambling to establish substantial retail outlets in urban shopping districts of Chinese cities. Louis Vuitton has 36 stores in 29 cities in China, Gucci 39 and Hermes 20

\footnotetext{
${ }^{4}$ According to the World Bank (2011) the per capital income range for the lower-middle-income group of countries is $\$ 996$ through $\$ 3,945$.
} 
(McKinsey, 2011). The well-known fashion brand Burberry has 53 stores in China. Driven by its high sales in China, it had an excellent year in 2010; Chinese sales jumped by 30 percent over its 2009 figures (Barrett, 2011). In 2010, a global recovery year, luxury goods market became revitalized in China. According to a market survey in 17 Chinese cities by McKinsey (2011), this market was on track to reach Rmb 180 billion (\$27 billion) by 2015. At this point, China will account for over 20 percent of the global luxury goods market, surpassing Japan as the world's largest luxury goods market.

\section{Second Largest Importing Economy}

As industrialization progressed, China became an insatiable consumer and large importer of industrial raw materials, intermediate inputs, technology and consumer goods (Das, 2011b). With $\$ 1,006$ billion worth of imports in 2009, China is the second largest importer in the world after the US (WTO, 2010). China is the largest importer of energy and several other important industrial raw materials and resources. As China's commodity imports increased, their world market prices firmed up, which in turn benefited the commodity exporting economies.

China's role as a large importer influences both the regional and global economies. Its rapidly rising imports of parts and components from the neighboring East and Southeast Asian economies are of enormous significance to them. They supported strong economic expansion in these economies. These countries have become a part of China's export ecosystem. China's imports from these Asian countries rose much faster than its exports to them. For many developing economies and EMEs, rapid growth in exports to China became an important contributor to growth. In particular, for several Asian economies, notably Korea and Taiwan, Chinese imports were responsible for one-half of their export increase.

China is also credited with helping the long-moribund Japanese economy. Its large imports also contributed to the firming of oil and commodity prices. China's status in the domains of multilateral trade, global financial markets and manufacturing output catapulted it over its rival economies. China has recorded very high import growth rates for consumer goods —about 15 percent annually for the last 15 years. This is much higher than the world average of 10 percent (IMF, 2010).

\section{Manufacturing Behemoth}

In the post-1978 period, the manufacturing sector became a significant driver of Chinese economic growth. China succeeded with its unorthodox strategy in rapid industrialization. It not only turned from an agrarian to a vigorous and internationally competitive manufacturing economy but it also integrated well into regional and global manufacturing products and services markets, carving an imperious niche for itself in the regional and global production networks. What is atypical and surprising is that China was able to do this despite the initial lack of financial sector development. 
The Chinese government adopted a wide array of industrial policies in an unorthodox manner to support what it referred to as a "national team" of large state-owned enterprises. The ultimate objective of this strategy was to create large firms that could eventually become globally competitive. This policy was in direct contrast to the prevailing trend of liberalization and globalization and against the grain of what is known as the Washington Consensus. Instead of the "invisible hand", the visible hand played a decisive role in China's strategy. These national team enterprise groups and subsidiaries performed well with respect to a number of performance measures (Sutherland, 2007).

Although China's manufacturing enterprises are a formidable competitor in the global markets to those in the other Asian EMEs, it successfully competes with all the three groups of economies: namely, the advanced industrial economies, the EMEs and developing economies. McKay and Song (2010: 2) contend that China was able to move to the "center of the world (economic) affairs through manufacturing-led development". China became a gigantic manufacturing economy and is frequently referred to as a "manufacturing juggernaut" or "world's factory" in the economic and financial press. It occupies a large share of global production in several industries like toys, bicycles, microwave ovens, shoes, textile and apparel, televisions, air conditioner, mobile phones, washing machines, refrigerators.

About one-third of the value-added of the Chinese manufacturing sector is exported and the rest is considered substitutable with foreign goods in the domestic economy. In 2010, China accounted for 15 percent of the world value-added in the manufacturing industries. This proportion is the same as that for Japan (OECD, 2010). Productivity growth in the manufacturing sector has been high. Growth accounting analysis by Bosworth and Collins (2008) led to the conclusion that TFP growth in the manufacturing sector contributed 55 percent of output growth in the manufacturing sector between 1995 and 2005.

Rapid industrialization progressed with greater spatial concentration and increasing regional specialization of industrial activities. Long and Zhang (2010) show increasing interconnections among firms in the same industry as well as those in the same region. Industries have become increasingly spatially connected and regions have become increasingly specialized. Industrializing firms followed Michael Porter’s industrial cluster concept (Porter, 2000). The manufacturing sector in China has emerged as strong and globally competitive. It is difficult to compete with in a large range of manufactured products. In 2010, the US held the top spot in manufacturing output, however it is poised to relinquish this distinguished status to China in 2011 (Marsh, 2010). This will end a 110year run of the US as number one nation in factory production. ${ }^{5}$ According to the Global

5 According to the IHS Global Insight, a Boston-based forecasting company, in 2009 the US was responsible for 19.9 percent of world manufacturing output, compared with 18.6 percent for China. The US managed to stay ahead despite a steep fall in factory production due to the global recession. In 2011, on the basis of IHS's estimates, China's factory output will amount to $\$ 1,870$ billion, a fraction ahead of the projected US figure for the year (cited in Marsh, 2010). 
Wind Energy Outlook (2010), China overtook the US as the world leader in wind power in 2010. According to the 2010 report, China's installed wind capacity has grown exponentially, from $0.3 \mathrm{GW}$ in 2000 to $42.3 \mathrm{GW}$ in 2010; it accounted for 22 percent of the world's total wind power capacity (GWEC, 2010).

A significant fraction of exports are products that are designed in other parts of the world, frequently by firms in the advanced industrial economies. This is called processing trade (section 2.3). China development of this kind of contract manufacturing capability has been extraordinary. Contract manufacturing enabled Chinese industrial firms to develop close relations with those in the advance industrial economies. This means that China's own industrial success is tied to that of its business partner firms and countries. The contract manufacturing activity ranges over a wide array of industrial products, from toys manufactured by Mattel, or personal computers (PC) by Lenovo to highly sophisticated components for the Airbus. Although China has emerged as a manufacturing base for firms around the globe, the sheer size of its industrial sector and its rapid growth has caused challenges for many business firms and even economies (Feenstra and Wei, 2010).

In several major industrial subsectors, China became the largest producer during the 2000s. For instance, it overtook the US in steel production about a decade ago and the European Union in 2003. It surpassed Korea in 2010 to be the world's largest shipbuilder in terms of shipbuilding capacity and new orders. Also, in 2010 China ploughed more than $\$ 1,000$ billion into new buildings projects. This construction boom propelled it to the top of global construction, surpassing the US for the first time (PwC, 2011). Another notable industry where China is a confirmed global leader is passenger cars, excluding light commercial vehicles. China overtook the US in 2006. By 2010, it was producing between a fifth and a quarter of total global auto production. As domestic household income rises, the manufacturing sector output is bound to grow larger. However, given the background of global imbalances, China needs to change it trajectory of industrialization. As noted below, efforts are afoot to turn its external demand biased industrialization towards domestic demand. During the first half of the twenty-first century, regional and global economies may well bear the imprint of China's manufacturing-led economic development. Their growth patterns may in turn be shaped by it.

\section{A Burgeoning de novo Private Sector}

In the early 1980s, as the reforms progressed, the government began downgrading the role and significance of the SOEs. A large number of them were incurring losses, some of them heavy. In 1984, SOEs were asked to devise shape-up strategies, strengthen their 
management capabilities and be commercially viable. Gradually small and medium private sector enterprises began to be established. They were officially encouraged more after 1990 . The state sector had to abandon food and beverages, textiles and apparels, home appliances and the other consumer goods industries for the private sector. Former state monopolies in finance, electricity, telecommunications, railroads, civil aviation and petroleum were also legally opened for private sector business firms.

Over the preceding three decades, the private sector enterprises had made a large contribution to rapid GDP growth and employment generation. In the post-1990 period this sector became more dynamic. Not only have a large number of them established themselves well but they are also devising new business models, production processes and management systems. They are also known for training personnel and nurturing talent. Accession to the WTO stimulated the private sector hugely. Private enterprises also pressured the SOEs to become more efficient. The long-term trend is that in terms of production and assets the weight of the private sector enterprises has steadily increased and that of SOEs declined. The share of private sector enterprises in industrial production was 80 percent in 2008 (WB, 2010). ${ }^{6}$

In China a lot of talent, determination and perseverance are needed for the private sector business firms to establish because despite the constitutional amendment of 2002, which gave them rights equal to those of the public sector, they are still frequently discriminated against. Several major markets and industrial sectors have still been regarded as off limits for them. They have limited access to bank credit and the risk-averse banks show little interest in servicing their credit needs. State-owned banks, which dominate the banking system, particularly shun smaller firms. Even in 2009, 80 percent of bank credit went to the SOEs (Zhang, 2011).

The private sector firms increasingly rely on informal financial markets, which are becoming progressively more mature. They tend to save costs through maintaining lower inventory and have to rely on retained earnings. Undoubtedly great deal of variations exists in financial access among private firms; usually smaller private firms face more financial constraints than the larger ones. Access of large and established private firms to bank finance is usually equal to their SOE counterparts (Hale and Long, 2011). Private sector enterprises also do not enjoy many official benefits that SOEs do. They need financial and policy support. Private sector business firms frequently have to maintain close ties with the SOEs and survive and prosper on their periphery. The most critical financial difficulty that private sector enterprises face in China is in the area of long-term funds to make investments for growth. Future financial reforms need to make this their high priority.

Often credit for China's successful private manufacturing sector is assigned to its bureaucracy. According to this line of thinking, it is the heavy role of the so-called visible hand that made China a successful manufacturing giant. The term "state-directed capitalism” is frequently used to describe China’s brand of capitalism. Important role

\footnotetext{
${ }^{6}$ See World Bank (2010a), Box 1, p. 3.
} 


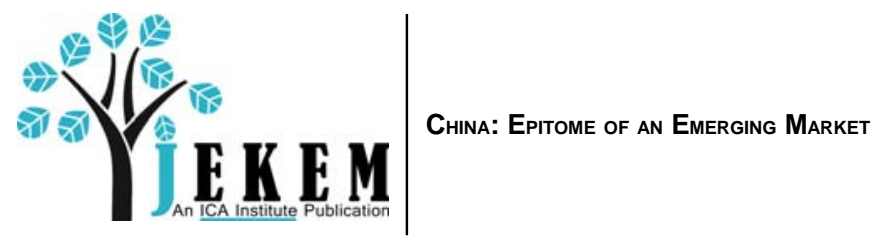

played by the state cannot be denied. It has earnestly endeavored to eliminate both physical and technological obstacles commonly faced during the early and middle stages of industrialization. To eliminate the former state built physical infrastructure and to remove the latter it facilitated transfer of foreign technology. Although this imperative role of the state should be acknowledged, China's industrial vigor and dynamism owes much to what has been happening from the bottom up. Comparable to the celebrated Mittelstand of Germany, China has a multitude of vigorous private enterprises. The Economist (2011, p. 11) christened it "a fast-growing thicket of bamboo capitalism." This bamboo capitalism "lives in a laissez-faire bubble”. Liu and Siu (2010) applied Generalized Method of Moments (GMM) estimator derived from a structural investment model to a large sample of Chinese industrial firms. They found robust evidence of listed private companies being more profitable than similar listed SOEs. The results from their benchmark estimation indicated that return on capital for a private sector firm was more than 10 percentage point higher than that of a similar SOE. The highest returns on equity were reported by unlisted private enterprises.

Notwithstanding the problems and scarcity of credit, the private sector did well during the Eleventh Five-Year Plan (2006-2010) period. According to the statistics released by the State Administration of Industry and Commerce, the number of private business firms increased from 4.3 million to 8.4 million during the Eleventh Five-Year Plan years. This was an average annual rate of growth of 14.3 percent and total growth of 93 percent. At the end of 2010, private enterprises accounted for 74 percent of all enterprises in China. They made a significant contribution to employment generation. Employment in the private sector exceeded 180 million at the end of 2010, 60 million more that at the end of 2005. The private sector enterprises employed approximately 7.87 million workers laid off by the SOEs in the last five years (Gang, 2011). Private sector investment also increased at a remarkable pace. These enterprises moved into new fields such as biological medicine, new energy, information technology and other strategic areas. Large private enterprises were also active in strategic acquisition of globally acclaimed foreign brands. Lenono's acquisition of IBM’s PC division and Geely Holding Group's acquisition of Volvo are cases in point.

\section{Summary and Conclusions}

This article defines EMEs in a simple and functional manner and shows that the Chinese economy not only has those characteristics but also is an epitome of an EME. It is the largest EME, well on its way to be an advance industrial economy in the fullness of time. A remarkable, perhaps even astonishing, economic event of the early part of the twenty-first century is that China has become the second largest economy in the world in a short span of three decades. Its stature in the global economy continued to increase and it contributed significantly to the recovery of the global economy from the global financial crisis (2007- 
9). From a long-term perspective China can convincingly be presented as a clear winner of globalization.

This article follows China's stellar growth path and the profound economic transformation it accomplished to become an EME in a remarkably short period of a generation. Its global stature also underwent a profound transformation. Not only it succeeded in alleviating poverty but also a substantive middle-class emerged in China, having a large purchasing power. It has grown into the second largest importing economy in the world, driving regional and global growth. An important development in this regard is that in the first decade of the twenty-first century it had become a manufacturing behemoth. Although state-owned enterprises are still active and have a meaningful place in the Chinese economy, its private sector has gradually emerged and despite difficulties has grown from strength to strength.

\section{References}

The Australian. 2009. “A Battle of Words”. Sydney, May 2, p. 16.

Barrett, C. 2011. “China Drives Burberry Growth”. The Financial Times, January 19, p. 17. Bernanke, B. S. 2006. “The Chinese Economy: Progress and Challenges”. Paper presented at the Chinese Academy of Social Sciences, Beijing, December 15.

Bernanke, B. S. 2000. “Japanese Monetary Policy: A Case of Self-Induced Paralysis” in R. Mikitani and A.S. Posen (eds) Japan's Financial Crisis. Washington DC. Institute of International Economics. pp. 149-166.

Bosworth, B. and S.M. Collins.2008.“Accounting for Growth: Comparing China and India”. Journal of Economic Perspectives. Vol. 22. No. 1. pp. 45-66.

Chadha, R. and P. Husband. 2007. The Cult of the Luxury Brand. Hong Kong: NB Publishing.

Chaudhury, S. and M. Ravallion. 2007. "Partially Awakened Giants: Uneven Growth in China and India”, in L. A. Winters and S. Yusuf (eds), Dancing with Giants: China, India and the Global Economy. Washington, DC: World Bank, pp. 175-210.

Chen, S., G. H. Jefferson and J. Zhang. 2011. "Structural Change, Productivity Growth and Industrial Transformation in China”. China Economic Review, Vol. 22, No. 1, pp. 133-50.

Chenery, H. B., S. Robinson and M. Syrquin. 1986. Industrialization and Growth: A Comparative Study. New York: Oxford University Press.

Dahlman, C.J. 2010. “Global Challenges from the Rapid Rise of China”. Oxford. Oxford University. Department of International Development. RMD Working Paper Series No. 41. July 13.

Daily Telegraph. 2011. “Rolls Royce Sets Record Car Sales in 2010”. January 11. 
Das, Dilip K. 2011a. Asian Economy: Spearheading the Recovery from the Global Financial Crisis. London and New York: Routledge.

Das, Dilip K. 2011b. “China in the Domain of International Business”, Human Systems Management, Vol. 30, No. 1, pp. 71-83.

The Economist. 2011. “Bamboo Capitalism”. March 12, p. 11.

The Economist. 2010a. “Jim O’Neill Looks at the Global Economy of 2036”. November 22, p. 64.

The Economist. 2010b. “The World’s Biggest Economy: Dating Game”. December 16, p. 40.

Farrell, D., U. A. Gersch and E. Stephenson. 2006. “The Value of China’s Emerging Middle Class”. McKinsey Quarterly. Available at https://www.mckinseyquarterly.com/The value of Chinas emerging middle class 1798

Feenstra, R. C. and S. J. Wei. 2010. “Introduction”, in R. C. Feenstra and S. J. Wei (eds), China’s Growing Role in World Trade. Chicago: University of Chicago Press. pp. 1-31.

Gallup. 2011. World Affairs. February. Available on the Internet at http://www.gallup.com/poll/146099/China-Surges-Americans-Views-Top-WorldEconomy.aspx?version=print.

Gang, X. 2011. “Boosting the Private Sector”. The China Daily, February 12, p. 5. Global Wind Energy Council (GWEC). Global Wind Energy Outlook 2010. Brussels. October.

Golley, J. and L. Song. 2010. “Chinese Economic Reforms and Development”, in R. Garnaut, J. Golley and L. Song (eds), China: The Next Twenty Years of Reform and Development. Canberra: The ANU Press, pp. 1-15.

Hale, G. and C. Long. 2011. "What are the Sources of Financing for Chinese Firms?" in Y.W. Cheung (ed) The Evolving Role of Asia in Global Finance. Bingley. UK. Emerald Group Ltd. pp. 313-339.

International Monetary Fund (IMF). 2010. Regional Economic Outlook: Asia Pacific. Washington, DC. April.

International Monetary Fund (IMF). 2011. World Economic Outlook: Update. Washington, DC. January 25.

Keping, Y.2009. Democracy is a Good Thing. Washington DC. The Brookings Institution Press.

Koresnikov-Jessop, S. 2010. “Swiss Makers Reward the Chinese Market”. The New York Times, March 17, p.16. 
KPMG. 2010. “Refined Strategies: Luxury Extends its Reach across China”. Beijing, China. August 13. Available at http://www.kpmg.com/Ca/en/IssuesAndInsights/ArticlesPublications/Documents/Refined \%20Strategies\%20-\%20Luxury\%20extends\%20its\%20reach\%20across\%20China.pdf

Kuznets, S. 1979. “Growth and Structural Shifts”, in W. Galenson (ed.), Economic Growth and Structural Change in Taiwan. London: Cornell University Press, pp. 115-31.

Lawrence, R. Z. 2008. “China and the Multilateral Trading System”, in B. S. Eichengreen (ed.), China, Asia and the New Global Economy. Oxford: Oxford University Press, pp. 145-67.

Lewis, W. A. 1954. "Economic Development with Unlimited Supplies of Labor”. Manchester School of Economic and Social Studies, Vol. 22, pp. 139-91.

Liu, Q. and A. Siu.2010. “Institutions, Financial Development and Corporate Investment: Evidence from an Implied Return on Capital in China”. Hong Kong SAR. Hong Kong Institute of Economic and Business Strategy. University of Hong Kong. Paper No. 1162. July.

Long, C. and X. Zhang. 2010. "Patterns of China’s Industrialization: Concentration, Specialization and Clustering” (unpublished manuscript).

Lucas, R. E.1993. “Making a Miracle”. Econometrica, Vol. 61, No. 2, pp. 51-272.

Maddison, A. 2001. The World Economy: A Millennial Perspective. Paris: Organisation for Economic Co-operation and Development.

Maddison, A. 2006. “Asia in the World Economy 1500-2030”. Asian Pacific Economic Literature, Vol. 20, No. 2, pp. 1-37.

Marsh, P. 2010. “US Manufacturing Crown Slips”. The Financial Times, June 20, p. 14.

McKay, H. and L. Song. 2010. “China as a Global Manufacturing Powerhouse”. China and the World Economy, Vol. 18, No. 1, pp. 1-32.

McKinsey \& Company. 2011. Understanding China's Growing Love for Luxury. Shanghai. China. April.

Organisation for Economic Co-operation and Development (OECD). 2010. China in the 2010s: Rebalancing Growth and Strengthening Social Safety Nets. Paris. March.

Porter, M. E. 2000. "Location, Competition and Economic Development: Local Clusters in a Global Economy”. Economic Development Quarterly, Vol. 14, No. 1, pp. 15-34.

Prasad, E.S. and T. Rumbaugh.2004. "Overview” in E.S. Prasaud and T. Rumbaugh (ed) China's Growth and Integration into the World Economy. Washington DC. International Monetary Fund. pp. 1-4.

PricewaterhouseCoopers (PwC). 2011. Global Construction 2020. London. March 3. 
Rodrik, D. 2006. What's So Special about China's Exports? Working Paper No. 11947. Cambridge, MA: National Bureau of Economic Research. January.

Song, Z., K. Storesletten and F. Zilibotti. 2011. “Growing Like China”. American Economic Review, Vol. 101, No. 1, pp. 202-41.

Stimpfig, J. 2011. “The New Red Army”. The Financial Times. April 2. p. 10.

Summers, L. H. 2010. “Parting Words” .New York. The Wall Street Journal. November 22. p. 11.

Summers, L. H. 2007. “The Rise of Asia and the Global Economy”. Research Monitor. Special Issue 4-5.

Sutherland, D. 2007. China's 'National Team' of Enterprise Groups: How Has it Performed? Discussion Paper No. 23. Nottingham, UK: China Policy Institute, University of Nottingham.

Verspagen, B.1993. Uneven Growth between Interdependent Economies. Aldershot, UK: Avebury.

World Bank (WB). 2009. From Poor Areas to Poor People: China's Evolving Poverty Reduction Agenda. Washington, DC. March.

World Bank (WB). 2010. World Development Indicators 2010. Washington, DC.

World Bank (WB). 2011. “Country and Leading Groups”. Washington DC. Available on the Internet at http://data.worldbank.org/about/country-classifications/country-and-lendinggroups\#Low_income.

World Trade Organization (WTO). 2010. International Trade Statistics. Geneva. September.

Zhang, J. 2011. “China Backpedals”. Stanford, CA: Hoover University. January 12. 